\title{
APLIKASI MEDIA BATU APUNG PADA BIOFILTER ANAEROBIK UNTUK PENGOLAHAN LIMBAH CAIR RUMAH POTONG AYAM
}

\author{
Rhenny Ratnawati, Muhammad Al Kholif \\ Program Studi Teknik Lingkungan, Fakultas Teknik Sipil dan Perencanaan, \\ Universitas PGRI Adi Buana (UNIPA) Surabaya \\ Jl. Dukuh Menanggal XII Surabaya 60234 \\ E-mail: ratnawati@unipasby.ac.id
}

\begin{abstract}
Abstrak
Sistem biofilter anaerobik merupakan salah satu alternatif teknologi yang dapat diaplikasikan untuk menangani limbah cair Rumah Potong Ayam (RPA). Penelitian ini bertujuan untuk: 1) mengidentifikasi karakteristik limbah cair RPA dan 2) mengkaji efisiensi penyisihan kadar BOD dan COD dengan sistem biofilter anaerobik menggunakan media batu apung. Penelitian dilaksanakan selama 10 hari dengan adanya variasi volume reaktor yaitu $30 \mathrm{~cm} \times 30 \mathrm{~cm} \times 60 \mathrm{~cm}, 25 \mathrm{~cm} \times 25 \mathrm{~cm}$ $x 60 \mathrm{~cm}$, and $20 \mathrm{~cm} \times 20 \mathrm{~cm} \times 60 \mathrm{~cm}$. Penelitian dilaksanakan secara duplo sehingga dibutuhkan 6 buah reaktor yang terbuat dari bahan akrilik. Parameter yang diukur dalam penelitian ini adalah nilai suhu, pH, kadar BOD, dan COD limbah cair RPA. Hasil penelitian menunjukkan bahwa kadar BOD dan COD awal limbah RPA berturut-turut mempunyai nilai 1,65 mg/L dan 2,60 mg/L, dimana nilai ini melebihi baku mutu air limbah menurut Peraturan Gubernur Jatim Nomor 72 Tahun 2013 Tentang Baku Mutu Air Limbah Bagi Industri dan/ atau Kegiatan Usaha Lainnya. Penyisihan kadar BOD pada limbah cair RPA dengan menggunakan reaktor biofilter anaerobik bermedia batu apung sebesar 94\%, sedangkan penyisihan kadar COD mencapai $96 \%$.
\end{abstract}

Kata Kunci: Biofilter anaerobik, Biological Oxygen Demand (BOD), Chemical Oxygen Demand (COD), Limbah Cair Rumah Potong Ayam (RPA)

\begin{abstract}
An anaerobic biofilter system is one of the alternative technologies that can be applied to handle the chicken slaughterhouse. This study aims to: 1) identify the characteristics of chicken slaughterhouse liquid waste and 2) assess the efficiency of removal of BOD and COD content with anaerobic biofilter system using a pumice medium. The study was conducted for 10 days with variation of reactor volume $30 \mathrm{~cm} \times 30 \mathrm{~cm} \times 60 \mathrm{~cm}, 25 \mathrm{~cm} \times 25 \mathrm{~cm} \times 60 \mathrm{~cm}$, and $20 \mathrm{~cm} \times 20 \mathrm{~cm} \times$ $60 \mathrm{~cm}$. The research was done in duplo, therefore 6 sets of acrylic material reactor were utilized. The parameters measured in this study were temperature, $\mathrm{pH}, \mathrm{BOD}$, and COD of chicken slaughterhouse wastewater. The results showed that BOD and COD levels of initial chicken slaughterhouse waste were $1.65 \mathrm{mg} / \mathrm{L}$ and $2.60 \mathrm{mg} / \mathrm{L}$, respectively, which exceeded the quality standard of waste water according to East Java Governor Regulation No. 72 of 2013 on Water Quality Standards Waste for Industry and/ or Other Business Activities. The removal of BOD content in chicken slaughterhouse liquid waste by using an anaerobic biofilter bolder with pumice stone was $94 \%$, while COD removal was $96 \%$.
\end{abstract}

Keywords : Biofilter anaerobic, Biological Oxygen Demand (BOD), Chemical Oxygen Demand (COD), Wastewater chicken slaughterhouse

Dikirim/submitted: 21 November 2017

Diterima/accepted: 27 Desember 2017 


\section{PENDAhULUAN}

Aktifitas pemotongan ayam pada Rumah Potong Ayam (RPA) menghasilkan limbah cair. Limbah ini berasal dari air bekas pembersihan tempat pemotongan dimana didalamnya telah bercampur darah, tulang-tulang kecil, serta air bekas pembersihan isi perut (Tarntip dan Thungkao, 2011). Limbah cair RPA mempunyai kadar bahan organik dan nutrien yang tinggi (Kholif dan Ratnawati, 2017; Ratnawati dan Trihadiningrum, 2014). Selain itu, limbah cair RPA ini mengandung berbagai mikroorganisme yang kemungkinan bersifat patogen, diantaranya bakteri Bacillus subtilis, Bacillus thuringiensis, Lysinibacillus fusiformis, protozoa, dan benih gulma (Tarntip dan Thungkao, 2011; Ratnawati dkk., 2016). Limbah cair RPA tersebut belum dikelola dengan baik, biasanya langsung dibuang ke badan air tanpa adanya pengolahan terlebih dahulu. Hal ini menyebabkan pencemaran air permukaan dan tanah. Terlebih isi perut (rumen) dan usus yang terdapat pada limbah cair RPA dapat meningkatkan jumlah padatan pada badan air.

Alternatif teknologi yang dapat diaplikasikan untuk menangani limbah cair RPA cukup beragam. Salah satu teknologi yang sesuai dengan karakterisasi limbah adalah sistem biofilter anaerobik. Pengolahan secara anaerobik banyak digunakan untuk pengolahan limbah cair RPA karena mampu menyisihkan bahan organik, biaya operasional rendah, dan pemeliharaan yang relatif mudah. Penelitian terdahulu melaporkan sistem biofilter anaerobik telah berhasil digunakan untuk pengolahan limbah cair RPA adalah Masse dan Masse (2001), Said dan Firly (2005), Said dan Yudo (2006), Amorim dkk. (2007), Sugito (2013), Kholif dan Ratnawati (2017).

Penelitian yang dilakukan oleh Masse dan Masse (2001) mengolah limbah cair Rumah Potong Hewan (RPH) menggunakan metode Anaerobic Sequencing Batch Reactors (ASBRs) dicapai efisiensi penyisihan kadar Chemical Oxygen Demand (COD) sebesar 92\%. Said dan Firly (2005) menggunakan biofilter anaerobik dengan media sarang tawon diperoleh efisiensi penyisihan kadar Biological Oxygen Demand (BOD) sebesar 89\%. Penelitian mengenai rancang bangun Instalasi Pengolahan Air Limbah (IPAL) RPA dengan proses biofilter anaerobik oleh Said dan Yudo (2006) mampu menyisihkan kadar BOD sebesar 88,79\%. Amorim dkk. (2007) menerapkan sistem Upflow Anaerobic Sludge Blanket (UASB) pada Rumah Potong Unggas dicapai efisiensi penyisihan kadar COD sebesar $80 \%$. Pengembangan reaktor biofilter terpadukan dengan teknologi filtrasi untuk mengolah air limbah domestik menjadi air bersih mampu menyisihkan kadar BOD dan COD masing-masing sebesar 98\% 
(Sugito, 2013). Kholif dan Ratnawati (2017) menyimpulkan penyisihan beban pencemar limbah cair RPA mencapai $98 \%$ menggunakan reaktor biofilter dengan media karbon aktif.

Metcalf dan Eddy (2004) menyatakan bahwa biofilter (submerged filter) merupakan reaktor yang dikembangkan dengan prinsip mikroba tumbuh dan berkembang pada suatu media filter dan membentuk lapisan biofilm (attached growth). Proses pengolahan air limbah dengan biofilter tercelup dilakukan dengan cara mengalirkan air limbah ke dalam reaktor biologis yang didalamnya diisi dengan media penyangga untuk pengembangbiakan mikroorganisme. Proses biologis dalam reaktor biofilter sebagian besar berhubungan dengan komposisi lapisan slime atau biofilm, yang menempel pada permukaan media. Proses pembentukan dan kolonisasi biofilm diawali dengan produksi slime dan kapsul bakteri yang menempel pada permukaan media. Penempelan kemungkinan pada awalnya terjadi karena adanya ikatan kimia dan gaya Van Der Walls. Lapisan biofilm yang sudah matang atau terbentuk sempurna akan tersusun dalam tiga lapisan kelompok bakteri, yaitu lapisan paling luar adalah sebagian besar berupa jamur, lapisan tengah adalah jamur dan algae, dan lapisan paling dalam adalah bakteri, jamur dan algae.

Penggunaan teknik anaerobik memberikan suatu penyelesaian dari sisi limbah cair RPA, karena ditinjau dari jumlah komposisi dan konsentrasi pencemarannya sangat sesuai untuk mengolahnya secara anaerobik yang dapat banyak menurunkan tingkat pencemaran tinggi dalam air limbahnya. Pada kondisi anaerobik akan terbentuk gas $\mathrm{H}_{2} \mathrm{~S}$ dan jika konsentrasi oksigen terlarut dalam reaktor cukup tinggi maka gas $\mathrm{H}_{2} \mathrm{~S}$ yang terbentuk tersebut akan diubah menjadi sulfat $\left(\mathrm{SO}_{4}\right)$ yang ada dalam biofilm. Selain pada zona aerobik, terjadi proses nitrifikasi, kadar $\mathrm{NH}_{4}-\mathrm{N}$ akan diubah menjadi kadar $\mathrm{NO}_{2}-\mathrm{N}$ dan $\mathrm{NO}_{3}-\mathrm{N}$. Selanjutnya pada zona anaerobik, kadar $\mathrm{NO}_{3}-\mathrm{N}$ yang terbentuk mengalami proses denitrifikasi menjadi gas $\mathrm{N}_{2}$ (Rini dkk., 2015).

Penggunaan batuan alami dalam menyisihkan polutan telah banyak diaplikasikan pada pencemar air baku maupun air limbah. Batu apung (pumice) adalah jenis batuan yang berasal dari lelehan magma pada lereng gunung api yang kaya akan silika, berwarna abu-abu terang hingga keputihan, mempunyai struktur yang berpori, dan ringan. Batu apung mengandung kapiler-kapiler halus sehingga dapat dijadikan absorben karena dapat mengadsorpsi pada kapilernya. Penggunaan batu apung telah berhasil dilakukan oleh Nurmaliakasih dkk. (2017), Widyaningsih (2016), Sulaiman dkk. (2016). Penelitian ini 
bertujuan untuk: 1) mengidentifikasi karakteristik limbah cair RPA dan 2) mengkaji efisiensi penyisihan kadar BOD dan COD dengan sistem biofilter anaerobik menggunakan media batu apung.

\section{BAHAN DAN METODE}

\subsection{Persiapan Alat dan Bahan}

Dalam penelitian ini alat dan bahan yang akan digunakan adalah :

1. Alat berupa reaktor biofilter anaerobik dari akrilik dengan ketebalan $5 \mathrm{~mm}$ yang dilengkapi dengan perlengkapan meliputi tandon air dari plastik, pompa, penyangga, pipa PVC dan sambungannya. Jirigen digunakan untuk pengambilan sampel limbah cair RPA. Media batu apung sebagai media yang diletakkan dalam reaktor biofilter anaerobik. Gambar reaktor yang akan digunakan dalam penelitian dapat dilihat pada Gambar 2.1.

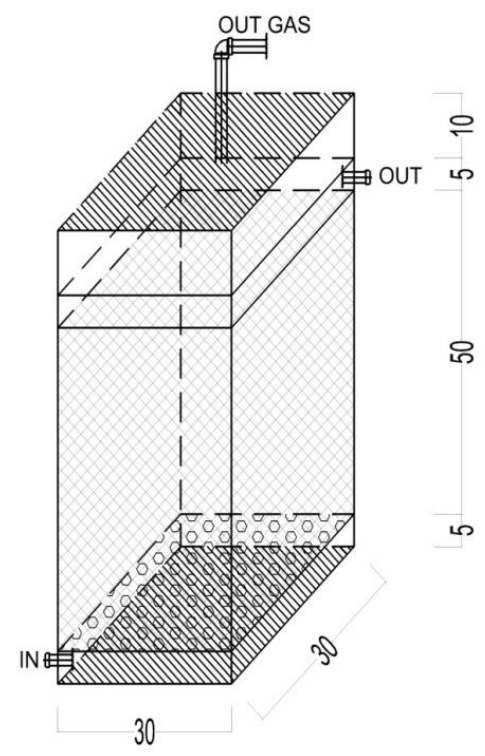

Gambar 2.1 Reaktor Biofilter Anaerobik

(Sumber: Kholif dan Ratnawati, 2017)

2. Bahan berupa limbah cair RPA setelah proses pencabutan bulu. Sampel diambil dari RPA daerah Bungurasih Utara, Kecamatan Waru, Kabupaten Sidoarjo. Setiap harinya RPA ini mampu melakukan pemotongan ayam sebanyak 700 hingga 800 ekor dan jika permintaan pasar sedang tinggi bisa mencapai 1000 ekor atau lebih per harinya. Titik pengambilan sampel dilakukan pada drum-drum pencucian ayam setelah bulunya sudah tercabut. 


\subsection{Tahap Pengumpulan Data}

Untuk mendapatkan data tentang efisiensi penyisihan kadar BOD dan COD pada limbah cair RPA maka dilakukan :

1. Analisis karakteristik awal limbah cair RPA. Pengujian ditujukan untuk mengetahui kondisi awal limbah cair RPA sehingga dapat diketahui penyisihan beban organik menggunakan reaktor biofilter anaerobik.

2. Variabel bebas yang digunakan dalam penelitian adalah variasi volume reaktor dengan rincian: $30 \mathrm{~cm}$ x $30 \mathrm{~cm}$ x $60 \mathrm{~cm} ; 25 \mathrm{~cm}$ x $25 \mathrm{~cm}$ x $60 \mathrm{~cm}$; dan $20 \mathrm{~cm}$ x $20 \mathrm{~cm}$ x $60 \mathrm{~cm}$.

3. Pengukuran parameter nilai $\mathrm{pH}$, suhu, kadar BOD, dan COD dilakukan selama 10 hari berturutturut.

4. Prosedur analisis kadar BOD dilakukan dengan metode winkler, sedangkan kadar COD dengan metode titrimetrik refluks tertutup (Eaton dkk., 2005).

\subsection{Tahap Analisis Data}

Analisis data dilakukan terhadap data yang diperoleh dari hasil analisis parameter, meliputi data penurunan kadar BOD dan COD limbah cair RPA serta parameter lain yang mempengaruhi. Analisis data dimaksudkan untuk mengolah data yang didapatkan selama penelitian untuk ditampilkan dalam bentuk data yang mudah dilihat dan dipahami. Data hasil penelitian yang didapat diolah menjadi bentuk tabel dan grafik sehingga mudah dianalisis. Semua hasil penelitian dilakukan analisis dan pembahasan secara detail sehingga tujuan penelitian dapat tercapai.

\section{HASIL DAN PEMBAHASAN}

\subsection{Karakteristik Awal Limbah Cair RPA}

Hasil karakterisasi awal limbah cair RPA disajikan pada Tabel 5.1. Tabel 5.1 menunjukkan bahwa nilai $\mathrm{pH}$ berada pada rentang nilai $\mathrm{pH}$ netral, yaitu 7. Nilai $\mathrm{pH}$ tersebut berada dalam kisaran nilai $\mathrm{pH}$ optimum untuk pertumbuhan mikroorganisme, sehingga mampu menguraikan limbah RPA. Kadar BOD dan COD berturut-turut mempunyai nilai $1.648 \mathrm{mg} / \mathrm{L}$ dan $2.603 \mathrm{mg} / \mathrm{L}$, dimana nilai ini melebihi baku mutu air limbah menurut Peraturan Gubernur Jatim No. 72 tahun 2013 Tentang Baku Mutu Air Limbah Bagi Industri dan/ atau Kegiatan Usaha Lainnya. Selain kadar bahan organik yang tinggi, kadar Total Suspended Solid (TSS) dan amonia $\left(\mathrm{NH}_{3}\right)$ juga melebihi baku mutu yang dipersyaratkan menurut Pergub Jatim No. 72 tahun 2013. Amorim dkk. (2007) menyatakan bahwa limbah cair yang dihasilkan 
dari aktifitas kegiatan di RPA menghasilkan limbah dengan konsentrasi bahan organik dan padatan tersuspensi yang tinggi.

Tabel 3.1 Hasil Karakteristik Awal Limbah Cair RPA

\begin{tabular}{lcrr}
\hline \multicolumn{1}{c}{ Parameter } & Satuan & Baku Mutu*) & Hasil Analisis \\
\hline Nilai pH & - & $6-9$ & 7 \\
Kadar BOD & $\mathrm{mg} / \mathrm{L}$ & 100 & 1.648 \\
Kadar COD & $\mathrm{mg} / \mathrm{L}$ & 250 & 2.603 \\
Kadar TSS & $\mathrm{mg} / \mathrm{L}$ & 100 & 1.210 \\
Kadar NH & 25 & 141 \\
Kadar minyak dan lemak & $\mathrm{mg} / \mathrm{L}$ & 25 & 180 \\
\hline
\end{tabular}

*) Pergub Jatim Nomor 72 Tahun 2013

\subsection{Nilai Suhu dan pH}

Secara keseluruhan, nilai suhu yang terjadi selama 6 hari penelitian tersebut berada pada nilai $30^{\circ} \mathrm{C}$ sampai dengan $44^{\circ} \mathrm{C}$. Kisaran suhu tersebut termasuk dalam kisaran suhu mesofilik $\left(20-45^{\circ} \mathrm{C}\right)$. Rentang kisaran suhu mesofilik ini berada dalam kondisi optimum untuk penguraian bahan organik. Nilai ini sejalan dengan hasil penelitian yang dilakukan oleh Ratnawati dkk. (2011) yang menyatakan bahwa kondisi suhu mesofilik merupakan suhu yang sesuai untuk proses biodegradasi. Selama proses penguraian bahan organik, mikroorganisme akan menguraikan substrat dan menghasilkan panas (Bernal dkk., 2009). Ketersediaan bahan substrat akan menyebabkan mikroorganisme tumbuh subur. Hal ini mengakibatkan mikroorganisme mendegradasi substrat dengan cepat, sehingga terjadi peningkatan suhu. Peningkatan suhu berasal dari energi panas yang dihasilkan mikroorganisme selama proses metobolismenya (Nolan dkk., 2011). Setelah hari ke-6 penelitian, terjadi perubahan nilai suhu. Nilai suhu berfluktuasi, namun cenderung mengalami penurunan. Penurunan nilai suhu ini dapat disebabkan karena bahan organik yang telah habis terdegradasi, sehingga mengakibatkan aktifitas mikroorganisme yang melambat. Guo dkk. (2012) menyatakan bahwa setelah bahan organik habis terdegradasi, suhu akan perlahan-lahan turun.

Dapat diamati selama penelitian berlangsung nilai $\mathrm{pH}$ berada dalam kisaran nilai $\mathrm{pH}$ netral dengan rentang 6,50-7,50. Nilai $\mathrm{pH}$ ini berada pada rentang nilai optimum untuk pertumbuhan mikroorganisme untuk mendegradasi bahan organik (BOD dan COD). Ratnawati dkk. (2016) menyimpulkan bahwa nilai pH netral dengan nilai 6-8 merupakan nilai yang optimum untuk pertumbuhan mikroorganisme. 


\subsection{Kadar BOD Limbah Cair RPA}

Selama proses pengolahan limbah cair RPA dengan biofilter anaerobik pada ketiga reaktor, hasil penurunan kadar BOD limbah cair RPA disajikan pada Gambar 3.1 dan Gambar 3.2.
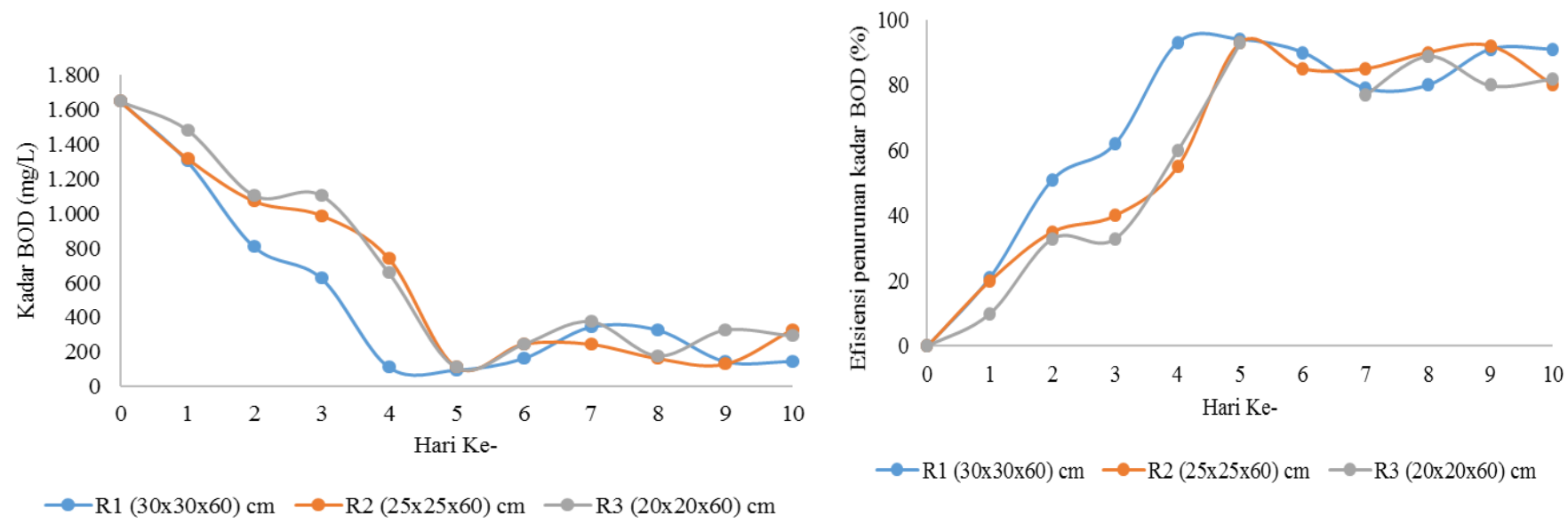

Gambar 3.1 Penurunan Kadar BOD Limbah Cair RPA Gambar 3.2 Efisiensi Penurunan Kadar BOD Limbah Cair RPA

Berdasarkan Gambar 5.3 dapat diketahui bahwa terjadi penurunan kadar BOD limbah cair RPA. Pada awal penelitian, kadar bahan organik tersedia dalam jumlah yang besar dan akan berkurang selama proses biologis berlangsung (Ratnawati dkk., 2016). Kadar BOD awal limbah cair RPA adalah 1.648 mg/L. Penurunan kadar BOD terlihat pada awal sampai dengan hari ke-8 penelitian pada ketiga reaktor penelitian. Penurunan kadar BOD tertinggi pada limbah cair RPA terjadi pada hari ke-5 pada ketiga reaktor. Pada reaktor 1 dengan volume reaktor 30x30x60 $\mathrm{cm}^{3}$, efisiensi penurunan kadar BOD mencapai 94\% pada hari ke-5 dengan kadar BOD adalah 98,88 mg/L (Gambar 5.4). Sedangkan efisiensi penurunan kadar BOD tertinggi yang terjadi pada reaktor $2\left(25 \times 25 \times 60 \mathrm{~cm}^{3}\right)$ dan $3(20 \times 20 \times 60$ $\mathrm{cm}^{3}$ ) dengan efisiensi penurunan kadar BOD mencapai 88\%, dengan kadar BOD adalah 115,36 mg/L (hari ke-5 penelitian).

Penurunan kadar BOD ini menunjukkan bahwa mikroorganisme bekerja pada kondisi yang optimum dalam menguraikan bahan organik yang ada pada limbah cair RPA (Kholif dan Ratnawati, 2016). Hal senada juga disimpulkan oleh Nolan dkk. (2011) yang menyatakan bahwa penurunan kadar BOD di awal penelitian berada pada fase aktif, dimana pertumbuhan mikroorganisme dan ketersediaan bahan 
organik tinggi sehingga aktifitas mikroorganisme untuk mendegradasikan bahan organik ikut meningkat. Cooperband (2002) dalam penelitiannya menyimpulkan bahwa saat sejumlah makanan (bahan organik), nutrien, air, dan udara tersedia, maka mikroorganisme akan bekerja cepat dalam mendegradasi material organik. Penurunan parameter limbah sangat bergantung pada aktivitas organisme dalam menyerap unsur hara, oleh karena itu semakin lama waktu pemaparan maka semakin besar materi organik yang tereliminasi melalui mekanisme biodegradasi (Dhamayanthie, 2000). Proses oksidasi yang dilakukan oleh mikroorganisme menyebabkan adanya penurunan bahan organik pada air limbah. Bakteri heterotrof yang ada pada limbah cair RPA dalam proses metabolismenya mengubah unsur-unsur dalam limbah menjadi bahan organik Penurunan konsentrasi bahan organik juga terjadi karena digunakan sebagai sumber nutrien untuk pertumbuhan oleh mikroorganisme.

Selain itu, media batu apung dalam reaktor biofilter anaerobik juga memiliki sifat adsorbsi sehingga mampu menyerap polutan baik zat organik maupun anorganik (Nurmaliakasih dkk., 2017). Molekulmolekul yang terkandung dalam air limbah akan menempel pada permukaan adsorben (media batu apung) akibat adanya proses kimia dan fisika sehingga terjadi proses difusi adsorben melalui pori-pori adosrben. Molekul polutan yang ada pada air limbah akan terserap pada bagian luar adsorben, kemudian bergerak ke pori-pori, dan selanjutkan masuk ke dinding bagian dalam. Penyerapan molekulmolekul polutan dalam pori-pori inilah yang akan menyebabkan terjadinya penyisihan kadar zat organik dalam air limbah (Widyaningsih, 2016).

Pada hari ke-8 dan ke-9 terlihat terjadi peningkatan kadar BOD pada ketiga reaktor. Peningkatan kadar BOD ini dapat terjadi karena adanya kematian pada mikroorganisme. Hal ini dapat disebabkan semakin berkurangnya nutrien dalam air limbah dan adanya pengaruh dari kadar senyawa kompleks yang sudah tidak dapat diuraikan, sehingga mikroorganisme tidak mampu lagi untuk melakukan proses penyisihan air limbah (Ratnawati dkk., 2011). Kematian mikroorganisme inilah yang mengakibatkan zat-zat organik yang telah terserap sebelumnya menjadi terlepas kembali, serta adanya mikroorganisme yang telah mati tersebut juga menambah kadar bahan organik dalam reaktor sehingga nilai konsentrasi BOD menjadi meningkat.

Jika dilihat dari variasi volume pada ketiga reaktor, terlihat bahwa efisiensi penurunan kadar BOD paling tinggi terjadi pada reaktor $1\left(30 \times 30 \times 60 \mathrm{~cm}^{3}\right)$, yaitu sebesar 94\%. Walaupun demikian, dapat diamati bahwa efisiensi penurunan kadar BOD tersebut tidak terjadi signifikan apabila dibandingkan 


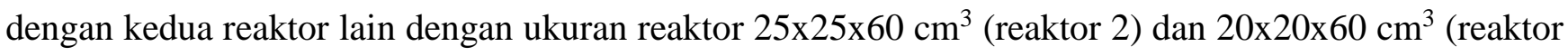
3). Reaktor 2 dan 3 mempunyai nilai efisiensi penurunan kadar BOD sebesar 93\%. Metcalf dan Eddy (2004) menyatakan bahwa semakin besar volume reaktor yang digunakan, maka semakin tinggi pula efisiensi penurunan kadar organik yang dihasilkan. Penelitian yang dilakukan oleh Said (2005) dapat disimpulkan bahwa dengan ukuran reaktor 130x25x50 $\mathrm{cm}^{3}$ efisiensi penurunan kadar BOD yang dihasilkan adalah 85-92\%. Sugito dan Kholif (2016) menyimpulkan bahwa biofilter dengan media bioball dan pecahan batu kali mampu menyisihkan kadar BOD pada limbah cair RPA dengan efisiensi mencapai $95 \%$.

\subsection{Kadar COD Limbah Cair RPA}

Hasil penurunan kadar COD limbah RPA menggunakan biofilter anaerobik media batu apung disajikan pada Gambar 3.3 dan Gambar 3.4. Berdasarkan Gambar 3.3 dan Gambar 3.4 dapat diamati bahwa terjadi penurunan kadar COD pada limbah cair RPA. Penurunan kadar COD terlihat pada awal penelitian sampai dengan hari ke-6 penelitian, kemudian kadar COD mengalami nilai yang berfluktuasi sampai dengan akhir penelitian.
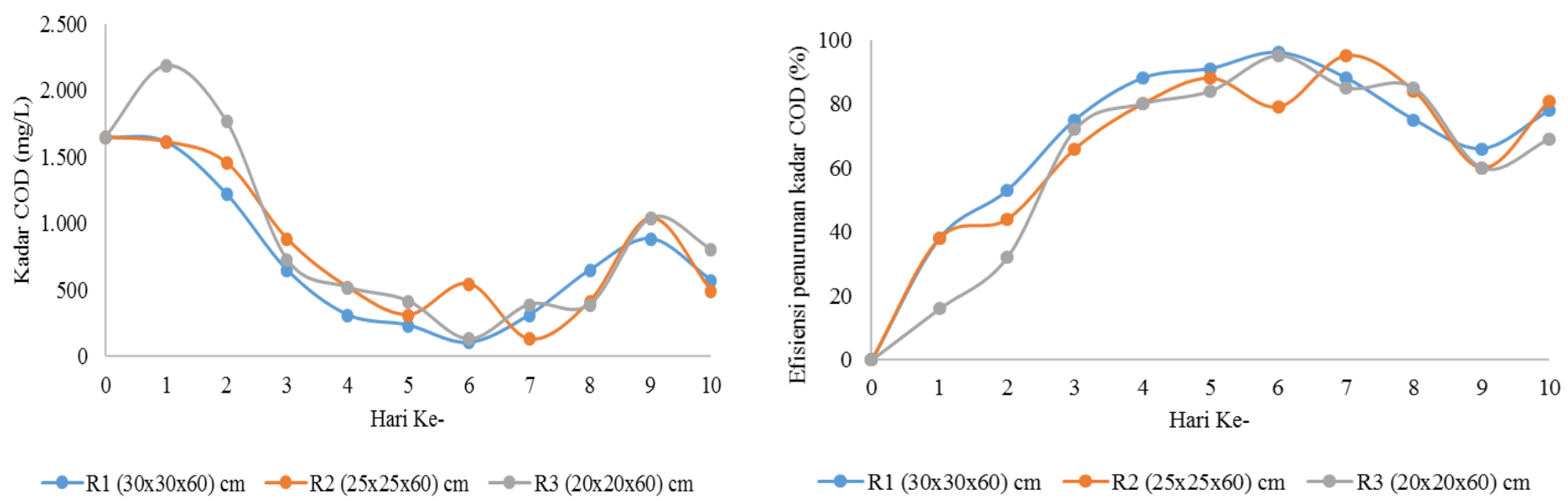

Gambar 3.3 Penurunan Kadar COD Limbah Cair RPA Gambar 3.4 Efisiensi Penurunan Kadar COD imbah Cair RPA

Kadar COD awal limbah RPA pada ketiga reaktor adalah 1.648 mg/L. Penurunan kadar COD tertinggi pada reaktor 1 terjadi pada hari ke-6 dengan nilai 104,12 mg/L, tingkat efisiensi penurunannya mencapai 96\%. Sedangkan reaktor 2 dan 3 mempunyai penurunan kadar COD tertinggi pada hari ke-7 dan ke-8 dengan nilai 130,15 mg/L. Efisiensi penurunan kadar COD pada reaktor 2 dan 3 bernilai $95 \%$. 
Penurunan kadar COD pada limbah cair RPA disebabkan oleh mikroorganisme menguraikan substrat yang ada pada limbah cair RPA. Pada awal proses penguraian, mikroorganisme membutuhkan waktu untuk beradaptasi dengan lingkungan \pm 6-12 jam. Setelah itu mikroorganisme akan tumbuh subur karena ketersediaan makanan (substrat) dan mulai mendegradasi substrat dengan cepat (Cooperband, 2002). Peningkatan suhu berasal dari energi panas yang dihasilkan mikroorganisme selama proses metobolismenya. Selama fase aktif (active phase) ini mikroorganisme akan cepat mendegradasi bahan organik dari kelompok karbohidrat, lemak dan asam amino (Nolan dkk., 2011). Saat ketersediaan makanan berkurang karena proses degradasi, maka aktivitas mikroorganisme juga akan berkurang. Berkurangnya aktivitas mikroorganisme ini menghasilkan penurunan suhu dari termofilik menjadi mesofilik pada fase selanjutnya (curing phase). Mikroorganisme yang muncul pada fase ini adalah bakteri, jamur dan Actinomycetes yang mendegradasi bahan organik dari kelompok selulose, hemiselulose, dan lignin menjadi humus (Nolan dkk., 2011; Tchobanoglous dkk., 1993). Efisiensi degradasi bahan organik akan terus menurun selama proses akibat reduksi pada ketersediaan sumber karbon dan polimerisasi komponen organik selama fase maturasi (Cooperband, 2002).

Selain itu, penggunaan media batu apung pada biofilter anaerobik juga berperan dalam penurunan beban organik dalam limbah cair RPA. Widyaningsih (2016) melaporkan bahwa batu apung merupakan salah satu adsorben yang mempunyai sifat mengikat molekul dalam cairan pada permukaannya. Nurmaliakasih dkk. (2017) menyimpulkan bahwa efisiensi penyisihan COD sebesar $33 \%$ menggunakan media batu apung pada limbah cair industri karet dengan waktu tinggal selama 25 menit.

Setelah mencapai penurunan kadar COD tertinggi, rata-rata kadar COD di masing-masing reaktor mengalami fluktuasi kadar COD sampai dengan akhir penelitian. Selama proses biologis, kadar karbon dapat mengalami perubahan yang fluktuatif yang dapat disebabkan oleh bakteri yang mengalami kematian. Bakteri yang mengalami kematian tidak mendegradasi bahan organik tetapi terukur sebagai organik sehingga kadar COD meningkat (Cooperband, 2002). Di akhir penelitian, kadar COD akhir reaktor 1, 2, dan 3 berturut-turut adalah 572,66 mg/L; 494,57 mg/L; dan 806,93 mg/L. Sugito dkk. (2016) menyimpulkan bahwa biofilter dengan media bioball dan pecahan batu kali mampu menyisihkan kadar COD pada limbah cair RPA dengan efisiensi mencapai $96 \%$. 
Sama halnya dengan penurunan kadar BOD, terlihat bahwa perbedaan ukuran dan volume reaktor tidak berbeda jauh pada penurunan kadar COD limbah cair RPA. Efisiensi penurunan kadar COD pada reaktor $1\left(30 \times 30 \times 60 \mathrm{~cm}^{3}\right), 2\left(25 \times 25 \times 60 \mathrm{~cm}^{3}\right)$, dan $3\left(20 \times 20 \times 60 \mathrm{~cm}^{3}\right)$ berturut-turut adalah $96 \%, 95 \%$, dan 95\%. Hal ini mengindikasikan bahwa variasi perbedaan ukuran dan volume reaktor yang diberikan tidak mempengaruhi penurunan kadar COD pada limbah cair. Said (2005) menyatakan bahwa dengan ukuran reaktor $130 \times 25 \times 50 \mathrm{~cm}^{3}$ mempunyai nilai efisiensi penurunan kadar COD yang dihasilkan mencapai $85-92 \%$.

\section{KESIMPULAN}

Kesimpulan yang diperoleh dari penelitian ini adalah sebagai berikut:

1. Kadar BOD dan COD limbah RPA berturut-turut mempunyai nilai $1.648 \mathrm{mg} / \mathrm{L}$ dan $2.603 \mathrm{mg} / \mathrm{L}$, dimana nilai ini melebihi baku mutu air limbah menurut Peraturan Gubernur Jatim No. 72 tahun 2013 Tentang Baku Mutu Air Limbah Bagi Industri dan/ atau Kegiatan Usaha Lainnya.

2. Penyisihan kadar BOD pada limbah cair RPA dengan menggunakan reaktor biofilter anaerobik bermedia batu apung sebesar 94\%, sedangkan penyisihan kadar COD mencapai $96 \%$.

3. Biofilter anaerobik memiliki peranan yang penting dalam menurunkan beban pencemar pada limbah cair RPA. Oleh karena itu biofilter anaerobik sangat cocok untuk diterpakan pada pengolahan limbah yang memiliki beban pencemar yang tinggi seperti pada limbah cair RPA. Kedepannya diharapkan industri RPA dapat membangun IPAL dengan konsep teknologi biofilter anaeorobik karena kemampuannya dalam mengolah limbah dengan beban pencemar yang tinggi.

\section{UCAPAN TERIMAKASIH}

Penelitian ini didanai oleh Universitas Adi Buana Surabaya melalui Hibah Adi Buana Tahun Anggaran 2016, kontrak No. 020.2.7/LPPM/I/2017. Terima kasih kepada Rodhi Khoirul Habibi yang membantu penelitian ini.

\section{DAFTAR PUSTAKA}

Amorim A.K.B, De Nardi I.R, dan Del Nery V. (2007), Water Conservation and Effluent Minimization: Case Study of a poultry Slaughterhouse. Resources, Conservation and Recycling, 51: 93-100. 
Bernal, M.P., Alburquerque, J.A. dan Moral, R. (2009), Composting of Animal Manures and Chemical Criteria for Compost Maturity Assessmen, A Review. Bioresource Technology, 100: 54445453.

Cooperband, L. (2002), The Art and Science of Composting, A Resource for Farmers and Compost Producers, Center for Integrated Agriculture Systems. University of Winconsin-Madison.

Dhamayanthie, I. (2000), Pengolahan Limbah Cair Industri Textile dengan Proses Anaerob. Thesis Master, Program Studi Teknik Kimia, Program Proses Sarjana ITB Bandung.

Eaton, Andrew D., Clesceri, Lenore S., dan Greenberg, Arnold E. (2005), Standard Methods for The Examination of Water and Wastewater. $21^{\text {th }}$ edition, American Public Health Association, Washington.

Guo, R., Li, G., Jiang, T., Schuchardt, F., Chen, T., Zhao, Y., dan Shen, Y. (2012), Effect of Aeration Rate, C/N Ratio and Moisture Content on The Stability and Maturity of Compost, Bioresource Technology, 112: 171-178.

Kholif, M.A., dan Ratnawati, R. (2016), Removal Ammonia ( $\left.\mathrm{NH}_{3}\right)$ in Industrial Chicken Slaughterhouse by Anaerobic Biofilter, Prosiding Seminar Internasional the 1st Seminar on Environment and Health Toward SDG's Achievement 2030 Integration System on Environment and Health Sustainability. Hal. 171-179, Surabaya.

Kholif, M.A., dan Ratnawati, R. (2017), Pengaruh Beban Hidrolik Media dalam Menurunkan Senyawa Ammonia pada Limbah Cair Rumah Potong Ayam (RPA). Jurnal Waktu, 15 (1): 1-9.

Masse, D.I., dan Masse, L. (2001), The Effect of Temperature on Slaughterhouse Wastewater Treatment in Anaerobic Sequencing Batch Reactors. Bioresour. Technol. 76: 91-98.

Metcalf, and Eddy. (2004), Wastewater Engineering, Treatment and Reuse. Inc. Fourth Edition, International Edition. McGraw - Hill Companies, Inc. New York.

Nolan, T., Troy, S.M., Healy, M.G., Kwapinski, W., Leahy, J.J. dan Lawlor, P.G. (2011), Characterization of Compost Produced from Separated Pig Manure and Variety of Bulking Agents at Low Initial C/N Ratios, Bioresource Technology, 102: 7131-7138.

Nurmaliakasih, D. Y., Syakur, A., dan Zaman, B. (2017), Penyisihan COD dan BOD Limbah Cair Industri Karet dengan Sistem Horizontal Roughing Filtration (HRF) dan Plasma Dielectric Barrier Discharge (DBD). Jurnal Teknik Lingkungan Universitas Diponegoro Semarang, 6 (1): $1-12$. 
Peraturan Gubernur Jawa Timur Nomor 72 tahun 2013, Baku Mutu Air Limbah Bagi Industri dan/atau Kegiatan Usaha Lainnya.

Ratnawati R., dan Trihadiningrum Y. (2014), Slaughterhouse solid waste management in Indonesia. Journal of Biological Researches, 19: 69-73.

Ratnawati, R., Slamet, A., dan Hermana J. (2011), Efek Penambahan Unsur Kalium dan Aerasi terhadap Kinerja Alga-Bakteri untuk Mereduksi Polutan pada Air Boezem Morokrembangan, Surabaya. Prosiding Seminar Nasional VIII Teknik Lingkungan ITS dan Seminar Nasional VII Ikatan Alumni Teknik Penyehatan Indonesia (IATPI), Surabaya.

Ratnawati, R., Trihadiningrum, Y., dan Juliastuti, SR. (2016), Composting of Rumen Content Waste Using Anaerobic-Anoxic-Oxic $\left(A^{2} O\right)$ Methods. Journal of Solid Waste Technology and Management. 42 (2): 98-106.

Rini, IDWS., Ratnawati, R., dan Trihadiningrum, Y. (2015), Pola Perubahan Kadar N-anorganik pada Proses Pengomposan Limbah Padat Rumah Potong Hewan dengan Sistem Aerobik. Prosiding Seminar Nasional Manajemen Teknologi XXII, hal. A-49-1 s/d A-49-8.

Said, N. I. (2005), Aplikasi Bio-ball untuk Media Biofilter Kasus Pengolahan Air Limbah Pencucian Jean, JAI. 1 (1): 1-11.

Said, N. I. dan Firly. (2005), Uji Performance Biofilter Anaerobik Unggun Tetap Menggunakan Media Biofilter Sarang Tawon untuk Pengolahan Air Limbah Rumah Potong Ayam. Jurnal Air Indonesia, 1 (3): 1-6.

Said, N. I., dan Satmoko Y. (2006), Rancang Bangun Instalasi Pengolahan Air Limbah Rumah Potong Hewan (RPH) Ayam dengan Proses Biofilter. Jurnal Air Indonesia, 2 (1): 22-29.

Sugito (2013), Pengembangan Reaktor Biofilter Terpadukan dengan Teknologi Filtrasi untuk Mengolah Air Limbah Domestik menjadi Air Bersih. Jurnal WAHANA, 59 (2): 37-43.

Sugito, Karunia, B. D., dan Kholif, M. A. (2016), The effect of BOD Concentrate influetn to Remove Pollutant Load in Wastewater of a Chicken Slaughterhouse. ARPN Journal of Engineering and Applied Sciences. 11 (5): 3519-3524.

Sulaiman, F., Satrio, P., dan Wahyudin (2016), Analisis Kinerja Biofilter Media Kerikil dan Batu Apung untuk Pengolahan Limbah Cair Industri Tahu. Tugas Akhir Fakultas Teknik Universitas Sultan Ageng Tirtayasa. 
Tarntip. R., dan Thungkao, S. (2011), Isolation of Proteolytic, Lipolytic, and Bioemulsifying Bacteria for Improvement of the Aerobic Treatment of Poultry Processing Wastewater. Afr. J. Microbiol. Rsc 5 (2): 30-35.

Tchobanoglous, G., Theisen, H., dan Vigil, S.A. (1993), Integrated Solid Waste Management: Engineering Principles and Management Issues, McGraw Hill, International Editions, New York.

Widyaningsih, T. S. (2016), Breksi Batu Apung sebagai Alternatif Teknologi Tepat Guna untuk Menurunkan Kadar TSS dan BOD dalam Limbah Cair Domestik. Jurnal Teknologi Technoscientia, 8 (2): 194-201. 